
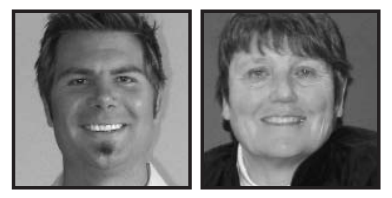

\title{
Stories of Sustaining: A Narrative Inquiry Into the Experiences of Two Beginning Teachers
}

\author{
Lee Schaefer \& D. Jean Clandinin, University of Alberta
}

\section{ABSTRACT}

Attending to early career teacher attrition as a problem of identity shaping and shifting enabled this narrative inquiry into two beginning teachers' experiences. We first created a fictionalized survey to show how their experiences could fit neatly into the dominant narratives of early career attrition. We then composed narrative accounts to show each participant's uniqueness. Seeing beginning teacher attrition through this lens allowed us to become attentive to sustaining moments in these teachers' lives.

"The teaching pool keeps losing water because no one is paying attention to the leak." (Peske et al., 2001, p. 306)

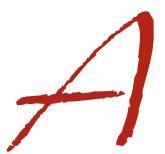

s Lee completed his autobiographical narrative inquiry ${ }^{1}$ we began to awaken to the importance of attending to beginning teachers' stories to live by (Connelly \& Clandinin, 1999), to their identities, to who they are and are becoming as teachers. We wondered if beginning teachers' imagined stories of who they were and who they were becoming as teachers, might shape whether or not they stayed in the profession. Would they become leavers, stayers, movers or shifters (Freedman \& Appleman, 2009)? Although teacher education programs may help to shape beginning teachers' stories to live by, it seems that, as Lawson (1983a, 1983b) and Lortie (1975) suggested, we think about becoming teachers long before we begin to teach. We live on school landscapes for much of our young lives and are shaped by our teachers and experiences on school landscapes. 
We adopted Clandinin and Connelly's narrative conceptual framework $(1995,1999)$ of identity² as "stories to live by." Stories to live by is a phrase that brings together teacher knowledge and teacher contexts. Teacher knowledge, their personal practical knowledge, is knowledge "imbued with all the experiences that make up a person's being. Its meaning is derived from, and understood in terms of a person's experiential history, both professional and personal" (Clandinin, 1985, p. 362). School context is understood metaphorically as a professional knowledge landscape composed of relationships among people, places and things, and is both a moral and intellectual landscape (Clandinin \& Connelly, 1995). The concept, stories to live by, is "given meaning by the narrative understanding of knowledge and context" (Connelly \& Clandinin, 1999, p. 4).

Following from this conceptualization, we understand individuals enter teacher education programs embodying stories to live by and, as part of their stories to live by, embody forward-looking stories of their imagined identities as teachers. This makes studying beginning teachers' experiences, both those experiences that brought them to teaching and those experiences that may help them stay in teaching, a very complex phenomenon.

In order to inquire into studying beginning teachers' experiences, we need to be aware of the multiple experiences each teacher has encountered. All beginning teachers' stories to live by, including their forward-looking stories, are much more than a result of their experiences in teacher education. Through attending to their stories to live by, we hope to add insight into what may help to keep them in the profession.

There are two main ways teacher attrition is conceptualized in the literature (Ingersoll, 1999): one way frames the problem of attrition with a focus on the individual teacher, the person. In this view, the person is seen in terms of individual factors such as age, gender, ethnicity, and educational background. The second framing examines the organizational contexts in which beginning teachers work, that is, with a focus on the context. In this view, attrition is seen in terms of contextual factors such as support, resources, collegiality, and classroom management. ${ }^{3}$

While there is discrepancy about the exact percentage of teachers who leave teaching within five years (from $5 \%$ to $50 \%$ ), "one very stable finding is that attrition is high for young teachers" (Guarino, Santibañez, \& Daley, 2006, p. 185). High rates of early career teacher attrition create a significant economic strain on the system (Hahs-Vaughn \& Scherff, 2008; Macdonald, 1999; Smith \& Ingersoll, 2004). In the United States, over 2 billion dollars are spent each year replacing teachers that leave the profession (Alliance, 2005, p. 2). 
Research shows trends and tendencies of early career teacher attrition from both individual and contextual frames. However, in our view, sanding beginning teachers' stories to fit within these trends and tendencies does not provide a sense of each teacher's stories to live by. When we use the metaphor of "sanding stories to fit into the boxes," we are referring to how narrow framings of teacher attrition and retention do not take lives into account. Thus, in looking at the sanding away of stories, we attended to who Shane and Kate were and are becoming. Using the metaphorical conceptualization of lives as being sanded away portrays Shane and Kate as more than trends and tendencies, more than graduates from particular programs and more than just beginning teachers. While they can be seen in that way, attending to their lives, that is, thinking narratively allows us to see their lives in motion, lives in the midst. Greene's (1995) view of seeing big and seeing small provides guidance.

To see things or people small, one chooses to see from a detached point of view, to watch behaviors from the perspective of a system, to be concerned with trends and tendencies rather than the intentionality and concreteness of everyday life. To see things or people big, one must resist viewing other human beings as mere objects or chess pieces and view them in their integrity and particularity instead. One must see from the point of view of the participant in the midst of what is happening. (p. 10)

\section{The Study and Participants}

We engaged in a narrative inquiry (Clandinin \& Connelly, 2000) into the experiences of two beginning physical education teachers as a way to understand their experiences as teachers and as people who are in the midst of composing their lives.

\section{Methodology}

The conceptual framework of narrative inquiry builds upon Dewey's view of experience. Through narrative inquiry, experience is studied through explorations of the personal/social, temporality, and place. These dimensions connect, as Clandinin and Connelly (2000) show, to Dewey's criteria of continuity (temporality) and interaction (sociality) and to situation (place). The narrative inquirer's gaze shifts from the 
personal (inward), that is, feelings, hopes and dispositions, to the social (outward) existential conditions as it simultaneously attends to temporality (backward and forward), and to place, that is, "to the specific concrete physical and topological boundaries of inquiry landscapes" (Clandinin \& Connelly, 2000, p. 51). These three dimensions constitute the metaphorical/conceptual space of narrative inquiry. Because narrative inquiry is relational inquiry, Lee, as researcher, co-composed both the field texts and the research texts with participants.

\section{Participants}

Two beginning teachers, Kate and Shane, participated. They graduated from the same physical education teacher education program and received combined degrees in physical education and education. They were in their first year of full-time teaching: Shane in a Grade 1-12 school where he taught grades 7 to 12; Kate in a high school, teaching grades 10 to 12 . They both taught other subject areas as well as physical education.

\section{Field Texts}

Lee met with Shane and Kate four times each. The first three meetings were one-on-one conversations, and the final meeting was a conversation among the three. Each conversation ranged between one and two hours, and were digitally recorded and transcribed. The conversations ranged from stories of the experiences that brought them to teaching; first year teaching experiences; possible sustaining experiences; and experiences with the research process.

\section{Sanding the Stories}

As we began to move from field texts to research texts, we realized we could fit their stories into the individual and contextual framings discussed earlier. We imagined a survey instrument and analyzed the transcripts to fit into our fictionalized survey tool. We created the survey drawing on current conceptualizations of beginning teacher attrition from the literature. We show the results in tables 1 and 2 . We then problematized this process and showed that in sanding beginning teachers' stories to fit into the conceptualizations, the stories to live by of each individual teacher are rendered invisible. 
Table 1:

\section{Sanding Kate's Stories}

\section{Beginning Physical Education Teacher Survey}

Participant Information:

Gender: Female Type of school (i.e., elementary, high school): high school

Age: 22

\section{Current year of teaching: 1}

Current classes you are teaching (please include grade level): Physical education 10, 20, Sports Performance 10

Education: Bachelor of Education, Bachelor of Physical Education

Approximate number of students at your school: 2400

Please answer questions according to the Likert scale: Bold the number that you feel is most appropriate.

1-very low 2-low 3-average 4-high 5-very high

Below each question there is an area for you to add comments if you choose.

1) How would you rate the support you have been given throughout your first year of teaching?

\section{Comments:}

"I was assigned a mentor teacher from the school, and we have had one meeting, and that was it."(Kate, Con 1, p. 13)

"I am like I don't know if I am doing the right thing, and no one is telling me I am doing a good job, and sometimes that is all I want to hear" (Kate, Con 1, p. 23).

2) Please rate your average level of frustration you have had over your first year of teaching.

\section{Comments:}

"In September and October I was like I cannot do this, cause that was when I did not know anything... September and October I was awful, I was so mean to everyone I was stressed out and not finding a balance, I could not do it, I was like screw this I don't know what I am going to do with my life, but it is not this. I am not having any fun at all" (Kate, Con 1, p. 32). 
3) On the Likert scale rate the level of frustration physical edu12345 cation has caused you throughout your first year.

\section{Comments:}

"I did not realize it is such a take-home job, but with PE it is not marking it is almost emotional, especially with girls there are so many things going on, and you're stressed cause you don't know how to fix it" (Kate, Con 1, p. 22).

4) Rate the level of frustration that came from feeling like you were teaching in a marginalized subject area.

\section{Comments:}

"oh you teach PE...you just play" (Kate, Con 3, p. 5).

"It sounds better than oh I am a student but it does not have the credibility of oh I teach LA, cause people are like you don't have any marking. That must be so easy, no prep work" (Kate, Con 3, p. 6).

5) Rate the level of classroom management and discipline issues that you have had throughout your first year.

\section{Comments:}

"It is baffling and sometimes it literally upsets me the amount of excuses I have in a day as to why they cannot participate, or just the refusal. They will take a 0 and be fine, and I am like how do you just take a 0" (Kate, Con 3, p. 7).

"You ask what is up, are you not feeling good, are you having a bad day. I hate PE, well why, I just hate it" (Kate, Con 3, p. 8). 
Table 2:

\section{Sanding Shane's Stories}

\section{Beginning Physical Education Teacher Survey}

Participant Information:

Gender: Male

Type of school (i.e., elementary, high school): Junior high school Age: $\quad 27$

\section{Current year of teaching: 1}

Current classes you are teaching (please include grade level): Physical education 7, 8, 9, Science 7, 8, 9 .

Education: Bachelor of Education, Bachelor of Physical Education

\section{Approximate number of students at your school: 500}

Please answer questions according to the Likert scale: Bold the number that you feel is most appropriate.

$$
\text { 1-very low 2-low 3-average 4-high 5-very high }
$$

Below each question there is an area for you to add comments if you choose.

1) How would you rate the support you have been given throughout your first year of teaching?

\section{Comments:}

"She did (come in to observe), it was in the context of my evaluation, formal evaluation, so it was you've already done bad, and I am just letting you know right now, it is not like let's sit down and make this better" (Shane, Con 2, p. 24).

2) Please rate your average level of frustration you have had over your first year of teaching.

\section{Comments:}

"That first six weeks, you know you're in the classroom sweating and tired and stressed out, and, you know, you're thinking, 'What am I doing here?'" (Shane, Con 1, p. 12).

3) On the Likert scale rate the level of frustration physical education has caused you throughout your first year.

\section{Comments:}

"I don't know if it's just that it seems to be the PE thing right, if there is coaching to be done it falls on the PE guy" (Shane, Con 1, p. 15). 
4) Rate the level of frustration that came from feeling like you 12345 were teaching in a marginalized subject area.

\section{Comments:}

"Everyone just thinks we don't do any planning or marking, all of these things that our status as a teacher is lower. We are there to be coaches and we also teach PE on the side" (Shane, Con 2, p. 19).

"I guess even at our school before this principal was there, I was talking to social teachers when they had to teach PE...they were just thrown in there cause they needed someone to do it; and they figure anybody can do it" (Shane, Con 2, p. 20).

5) Rate the level of classroom management and discipline issues that you have had throughout your first year.

\section{Comments:}

"I feel bad, it sucks the kids are bored, and again it comes back to the classroom management, maybe if I was able to plan more engaging lessons they would be less inclined to mess around" (Shane, Con 2, p. 12).

"I've got behavior problems and you try to solve them resorting back to just disciplinarian style, you are losing relationships, at the end of the day it is like, 'What was I doing here all day?'" (Shane, Con 2, p. 12).

\section{Disrupting the Sanding of Stories}

By analyzing the field texts in this way, that is, by sanding the storied lives, it is apparent that Kate's and Shane's stories can fit into current conceptualizations. We see them as part of the trends, tendencies and patterns, that is, we see small (Greene, 1995). However, Shane's and Kate's individual experiences are lost; their stories are reduced to common trends, when they are surely not. We knew something of their unfolding lives in motion: they taught in different professional landscapes shaped by different plot lines and different characters; they grew up in different places, with different parents, different families and different values; they came to teaching living out different stories and told unique imagined stories of who they would be as teachers. Through their stories we saw their lives. 


\section{Imagined Stories to Live By: Bridging the Gap}

All my writing is about the recognition that there is no single reality. But the beauty of it is that you nevertheless go on, walking towards utopia, which may not exist, on a bridge which might end before you reach the other side (Young, n.d.).

Young's words helped us imagine this bridge as the space that beginning teachers are in/on as they try to live out their imagined stories of being teachers on their school landscapes. How does their search for utopia shape beginning teachers' stories to live by on their professional and personal landscapes? If these beginning teachers leave teaching, do they realize the bridge may not reach the other side?

We are not the first to attend to beginning teachers' experiences using an identity frame. Flores (2006) notes identity shifting is "a process that involves complex interplay between different, and sometimes conflicting, perspectives, beliefs, and practices that are accompanied by the development of a new identity" (p. 2021). Estola (2003) emphasizes, "teachers cannot separate their personal identities from their professional ones" (p. 181). Flores and Day (2006) allude to beginning teachers' struggles with negotiating their personal visions of who they want to be within school structures. Shane's and Kate's stories show their struggles as they tried to negotiate their personal and professional landscapes while hanging onto their imagined stories of who they wanted to be as teachers. Their stories of who they were going to be bumped against who they were expected to be as beginning physical education teachers (Clandinin et al., 2006).

This bumping encouraged both Kate and Shane to shift their stories to live by, to try to cross different metaphoric bridges to enable them to live imagined stories. The shifts they made in living on both their professional and personal landscapes seemed to enable them to have moments of feeling sustained. We noticed these shifts on their professional and personal landscapes were so intertwined that it was difficult to discern which experiences initiated the shifts. As they shifted, Shane and Kate caught glimpses of their imagined teacher stories to live by, the forward-looking stories with which they entered the profession. Within these glimpses Kate and Shane found moments that allowed them to continue to cross that metaphoric bridge. 


\section{From Field Text to Research Text}

In what follows we share story fragments which suggest threads that became apparent within Kate's and Shane's stories. Becoming attentive to beginning teachers' stories to live by and how they shift and change on their professional and personal landscapes may help us to better understand their stories of being sustained as teachers. 4

\section{Kate's Journey of Becoming a Teacher}

\section{Thread 1: Not a subject area}

I remember the exact moment that I wanted to be a teacher. I was 16 and I was volunteering with Sports Central... We started with 30 kids and by the end of the week we had 70...I was, like, this is so fun. I am playing with these kids all day and I was like I want to be a gym teacher... I started working in Sports Central because my brother passed away and instead of flowers we asked people to donate to Sports Central. We created a fund with the donations. That happened when I was in grade 10... gym class was the only class I could handle going to... These younger guys who were super fun and laid back, and they just wanted to play and that was it...And it was that passion, I was fortunate to have great classes, and good friends, but it's mainly that I understood then that sport can pull people together, that's why I wanted to be there...I could just be me...And I was like I want to create that environment for someone else. That was what inspired me...I felt like they were more inclined to think of me as a person, and not just a student. You know you were not a subject area to teach you were a person that needed things outside of those subject areas ${ }^{5}$ (Kate, transcript, March 4, 2010).

Kate's story alludes to the importance of physical education in her life. Kate's experience of losing her brother was difficult and her physical education class was her place of respite. She speaks of sport and physical education in a powerful way, but also speaks to the environment that was created. "You were not a subject area to teach, you were a person." Kate's stories of physical education drew forward experiences of being herself and having fun. Her imagined stories of teaching include these strong feelings. "I wanted to create that environment for someone else." 
Kate told other stories of what brought her to teaching. She storied herself as outgoing and interactive and saw that as fitting with being a teacher and noted being a teacher "was always a bit of a calling in a sense, like what I really need as a person to be satisfied" (Kate, transcript, March 8, 2010).

\section{Thread 2: Bumping of stories: Professional landscape}

September and October, I was trying so hard to seem like the expert in everything, especially to my kids, cause I felt like I had to prove something. I was faking confidence, like, I know how to do this... I just felt like I had to be way more strict and sort of almost like a bitch because I look so young and I am so small...you know you're told you have to be evil until Christmas, don't smile until Christmas so they (the students) don't take you for all you got...in university you are always told to never be their friends... I was always so stressed, nothing was good enough, I was never feeling satisfied (Kate, transcript, March $4,2010)$.

Although Kate's stories to live by as she entered the profession spoke of creating an environment that made her students feel like people, not a subject area, Kate felt she had to live out a different story. Being "strict," and being a "bitch" did not fit in to the story she told of physical education as she entered. The metaphorical use of bumping alludes to Kate's imagined story of teaching coming into conflict with the stories of school that shaped her teaching practice. For example, her need to be "per$f e c t$," and knowledgeable did not seem to fit with Kate's imagined story. Her stories to live by spoke of joy and of fun as more important than learning.

In Kate's stories to live by she valued how her physical education teachers were involved with students, yet spoke, in her beginning months, of standing on the sidelines and evaluating students. Other teachers in the school followed this procedure, so she felt it was expected. Although Kate spoke of her past physical education teachers as friends who made her feel like she mattered, on her professional landscape she distanced herself from students, and adhered to what she said she was told in university; "don't smile until Christmas or they will take you for all you got" (Kate, transcript, March 4, 2010).

\section{Thread 3: Bumping of stories: Personal landscape}

I still live at home and my Mom was like, you need to move out, you are awful to be around. I was barely seeing my friends, I was being an awful girlfriend and I was just mean to everyone. At school you put on this happy face, and when you get home you are so desperate to feel something not fake (Kate, transcript, March 4, 2010). 
Kate's stories to live by on her personal landscape seemed to create tensions not apparent before she began teaching. Although she spoke of putting on a happy face at school, she was not who she wanted to be on either landscape. At one point Kate mentioned she thought about leaving teaching, but did not know where to go. Kate's desperation to "feel something not fake" spoke of how she was not able to live her imagined stories on either landscape. The tensions on both her professional and personal landscapes created a dilemma. Feeling like she had to change something to survive to be herself, Kate began to cross the bridge she felt might allow her to live out her imagined stories. As she did so, her story began to shift to one that tried to incorporate more of her imagined stories.

\section{Thread 4: Shifting stories to live by}

I started to feel slowly more like myself and more content even though I was having crazy days at work, it was more bearable. That's when I was like ok I need to start doing more things just for me (Kate, transcript, March 4, 2010).

We do not know if experiences on her personal or professional landscape prompted Kate to begin shifting her stories to live by; the shifts happened simultaneously on both landscapes. When Kate spoke of feeling "more like herself" (transcript, March 4, 2010), she appeared to be catching a glimpse of her imagined story.

I was like, screw this supposed teacher hat I am supposed to have on. It is not working...I started just being me and said I would have fun, put myself out there. I found that kids were more likely to relax at the very least, and laugh a lot. So I went and said to them, my goal is to talk to each of you each class about anything, and even now a student said I love the fact that I worked at a deli and you remembered it. That was what my teachers did (Kate, transcript, March 4, 2010).

"Screw this supposed teacher hat."We wondered if Kate realized the shifts she pointed out were enabling her to live out a piece of her imagined stories as a teacher. Feeling "more like herself" illustrates a movement from doing what others thought was important to doing what she felt was important. Kate noted she had, in some ways, created the environment her physical education teachers created for her. In becoming more like herself, her story of her personality being a "perfect fit for teaching" (transcript, March 18, 2010), allowed her to connect with students. As Kate talked about the environment created, and the connections with students, she smiled. 
I was showing this girl how to do a stretch, and she was injured, and she looked so awkward, and we just started laughing for like five minutes... Like everyday if you could have a stellar thing and you, like, feel good, I am making a difference in this kid's life... She never learned the stretch, but at the same time when she is asked who her favorite teacher is, I may be one of them (Kate, transcript, March 18, 2010).

Although Kate referred to these "stellar things" as minor successes, these successes with students were significant in Kate's imagined stories. Kate's stories to live by spoke of shaping students' lives in positive ways and allowing them to have fun while engaged in physical education. In Kate's words and demeanor during this conversation, we saw the connections with students as sustaining moments. Were these "stellar things" glimpses of her imagined story?

There is much more to Kate's stories to live by and to her imagined stories. Along with stories of connections with students and "stellar things," Kate storied frustration from the bumping of her imagined stories with the stories she felt she had to live out on the professional landscape. We wonder what might happen next for her as a teacher. What happens to beginning teachers' stories to live by as they try to negotiate their imagined stories? How might beginning teachers see their new landscapes differently if they entered with knowledge of how school landscapes could be negotiated? We wonder if Kate's stellar moments will be enough to sustain her as a beginning teacher.

\section{Shane's Journey of Becoming a Teacher}

\section{Thread 1: Teacher of the house}

I grew up with a brother who is about the same age as me and he had some learning disabilities, so I really liked helping him out with his schooling. I also have a younger sister and I helped her along as well. Neither of my parents at the time when I was going through school had graduated from high school, so if there were any scholastic problems it was me that tried to solve them. So I guess I was always kind of the teacher in the house, and I have always enjoyed explaining things to people. That aha moment when you see them get it, and they are happy, and then you are happy because they are happy (Shane, transcript, March 1, 2010).

This fragment shows Shane was storied by himself, and by others, as a teacher long before he entered the profession. His desire to help others learn, 
become better, resonated throughout our conversations. Shane's imagined stories of himself as a teacher were ones that involved him enabling others to learn. Shane also spoke of other experiences that fostered his desire to become a teacher.

Shane spoke of teachers as well as coaches he storied as "being funny, good at their jobs," who "made learning easy" (transcript, March 1, 2010). Although he enjoyed these teachers, he did not want to force himself to become like them. He was aware, and believed it was important to create his own style. Shane's desire to "create his own style" (transcript, March 1, 2010) is in contrast to Kate's stories to live by. Later in our conversation, Shane told another story that brought him to teaching.

As I got older, um, and kind of started looking at education from a First Nations Perspective and seeing First Nations people falling through the cracks and stuff like that, that really kind of, like, helped to solidify the career choice for me... and now it is definitely a want, a desire to help kids and teaching seems to be a good avenue for that....kids just seem like the correct entry point... you can help save so many lives; it's a dramatic thing... I guess you hope to set them on the right track, to get the ball rolling, to help them on the right track (Shane, transcript, March 1, 2010).

Shane is of First Nations heritage. Through his words and passion he made evident that helping First Nations students is an important part of his stories to live by. Shane works in a school with a high First Nations population. He requested a placement there so he might fulfill his desire to impact First Nations children's lives.

\section{Thread 2: Bumping of stories}

I guess it was probably the build-up of like slogging through the mud, so to speak. Just getting worn down to the point where I had a class where I just, you know, my office I can see in the gym so it is not like I left my class unattended, but I just left the class and went and sat in my office, and I was just like what is going on here. This is not going the way I want it to. You reflect on the day and the week and you just find that things do not add up...just thinking how long can I go at this rate with this type of stress, and this type of running into a brick wall everyday? Eventually something was going to break, and I did not want it to be me physically or mentally, so I knew I had to change something (Shane, transcript, March 15, 2010).

We could construe these words as Shane becoming burned out. However, when we consider Shane's stories of wanting to keep students from "falling through 
the cracks," we wonder if the metaphoric "brick wall" may be his imagined stories bumping against the dominant stories shaping his professional landscape. Shane's metaphorical use of "slogging through the mud" creates an interesting image as Shane tries to cross the bridge to reach his imagined stories. The mud makes the process difficult.

I am only focusing on classroom management and planning and how am I going to get through the curriculum. And you know a lot of the relationships are not getting built because I don't have time. Unfortunately, the way things are going, you know I have created an adverse relationship with some of the harder students I need to be reaching... unfortunately I can't build relationships to get them to work, so I have to force them to work, which further polarizes it...I want a comfortable, relaxed atmosphere where we can joke around and have fun, but unfortunately you know with discipline problems that I am dealing with, all of that gets pushed to the side and I don't feel like I am being who I want to be in the classroom (Shane, transcript, March 8, 2010).

Shane's frustration as he spoke of the lack of relationships being built was clearly apparent in his voice. The juggling of teaching duties was getting in the way of relationship building. The management issues he faced, due to the lack of relationships, bumped with Shane's imagined stories of shaping students' lives in a positive way. Shane's long hours and the bumping of his imagined story with the stories he was living, were taking a toll. As Shane struggled with life on his professional landscape, his imagined story of who he would be as a teacher was also creating bumps on his personal landscape.

I pictured first-year teaching, I guess just being out of school for the first time, as having more time than I did at school. School was booked up, especially me trying to pay for school. I was working 30 hours a week on top of my school schedule. So I [as a teacher] I saw myself joining sports leagues, or Friday night darts. That first summer me and some friends went to a big festival in Vancouver, and being able to do things spur of the moment, trips and that is kind of what I was hoping for. Like I said, that young urban professional (Shane, transcript, March 15, 2010).

Shane spoke often of the "young urban professional" he imagined himself becoming. He envisioned a life outside of school that allowed the freedom working a full-time job, and attending university at the same time, did not allow. He was spending less time with friends than he wanted to, and not living the lifestyle he hoped teaching would provide. Like Kate, Shane made the decision to change the stories he was living on both landscapes to try to create a bridge to his imagined stories. 


\section{Thread 3: Shifting stories to live by}

You talk about a breaking point of work and things like that, and I found that's what I had to do. I had to cut down my planning and marking and all the other things I was doing in the evening because the stress and frustration was boiling over and it was completely killing everything else that I had going on. So in order to keep my identity, keep myself sane and happy and healthy, I had to scale back what I was doing (Shane, transcript, March 15, 2010).

Although Shane spoke of shifting on the professional landscape, like Kate's shift, it is difficult to separate shifts on the professional landscape from shifts on the personal landscape. As Shane spoke of hanging onto his identity, did he mean hanging onto what is important to him as a person and a teacher? Shane felt spending more time with friends, and with students, rather than planning and marking, would allow him to sustain his identity, to sustain what was important to him.

I think that is the thing. Where I want to put my best is in the classroom, and so, you know, I am always going to be a little behind in my marking, my planning is probably never going to be quite as good because I want to be focused on what is going on in the classroom...by providing after school drop in floor hockey, by having a wrestling team, and volleyball team, doing the things that are extra curricular that cut in to my time to do all the other things I think it's just, it is going to get me farther (Shane, transcript, March 15, 2010).

When Shane spoke of "getting himself farther," we did not see this as moving himself up the school ranks. We saw Shane talking about getting himself farther by living his imagined stories, those stories built around plotlines of keeping students from "falling through the cracks," and being an adult that cares. Shane's decision to do less marking and planning was a way to try to catch a glimpse of his imagined stories.

Last semester I had a grade 12 class... they were literally my rock last semester...I would come in, they were really quiet... You know I would set them up, and we could play games, trying to play games with 8 students can be difficult, so I would try lots of different things, and they did anything I could ever ask them to do. I found I made more connections with that group; they were a little bit older, more mature (Shane, transcript, March 18, 2010).

Shane referred to this group of students as "his rock" a number of times. Shane's "rock", like Kate's"stellar thing", seemed to be something that allowed him to live his imagined stories, to create a sustaining moment. The connections with students 
are something that clearly stands out, as they link to Shane's imagined stories of teaching. We wondered if this was an experience that enabled Shane to experiment with, and to create, his own teaching style. This may have allowed him to create sustaining moments and to move farther across that metaphoric bridge, closer to his imagined stories. We wondered if these sustaining moments were enough.

I've got class averages of 50\%, so the kids are not getting the information I am giving them. I've got behavior problems and [if] you try to solve them by resorting back to just disciplinarian style you are losing those relationships. At the end of the day it is like what was I doing here all day. I did not build relationships and I did not pass on any knowledge (Shane, transcript, March 8, 2010).

Shane's frustration with the environment being created in his classes is evident. Shane's imagined stories of "aha moments" (transcript, March 1,2010) and "keeping kids from falling through the cracks" seem to bump hard against the professional landscape stories. How will this tension, created between Shane's imagined stories and the stories he is living out, shape his decision to stay or leave?

What will happen if Shane's next year looks similar to this one? How many years like this one will he endure? Will Shane stay long enough to tell if he has saved a student from "falling through the cracks"? Will Shane be able to "slog through the mud" long enough to cross the bridge to his imagined stories?

\section{Complexities in the Lost Sand}

In looking at the remnants of Kate's and Shane's lives that may remain after the sanding, we begin to awaken to how complex their sustaining stories really are. Although we focused on only certain aspects of Kate's and Shane's stories, we learned both Kate and Shane had stories to live by composed on their personal landscapes prior to beginning teaching. It was apparent these stories to live by bumped against the stories shaping their professional landscapes. As stories bumped, both Kate and Shane shifted their stories to live by in order to catch glimpses of their imagined stories; they tried to cross the metaphoric bridge. Although they both had sustaining moments that came out of these shifts on their personal and professional landscapes, it is difficult to tell if these sustaining moments will turn into stories that will sustain them in teaching. 
The changes Kate was making to her stories to live by allowed her to experience sustaining moments. Through becoming "more like herself" on the professional landscape she connected with students, had fun, and became "that teacher" (transcript, March 18, 2010). She re-created, at least in the stories she told herself, the environment that meant so much to her as a student in physical education.

For Shane, things are murkier, and perhaps messier. Although he made shifts on his personal and professional landscapes, it is difficult to tell if these shifts created the positive experiences. Kate's imagined stories were of creating a certain environment important to her, that was created for her as a student. Shane's imagined stories were different; he wanted to create his own style, experiment, and create a different environment. Shane's stories seemed to continue to bump after the shifts took place. It seemed that, at this time, the bridge to his imagined stories of "aha moments" and "keeping kids from falling through the cracks" could not be crossed.

What do we learn from attending to these stories? On the surface, Kate's and Shane's experiences are similar. As illustrated in tables 1 and 2, by analyzing their comments, sanding their stories and putting them into boxes, they fit nicely into common beginning teacher trends and tendencies. However Kate's and Shane's stories are far too complex and messy to fit neatly into boxes. Attending to the stories that brought Kate and Shane to teaching, the stories of their personal and professional landscapes, and their stories of moments of sustaining helps us see the complexities. Their stories are diverse, shifting and changing in different ways. This raises questions about the multiplicity of stories beginning teachers enter the profession with, and tell, as they negotiate their stories to live by and their imagined stories on their professional landscapes.

The interconnectedness between Kate's and Shane's personal and professional landscapes became apparent. The landscapes they lived within were so interconnected that, at moments, we could not differentiate them. "A narrative way of thinking about teacher identity speaks to the nexus of teachers' personal practical knowledge and the landscapes, past and present, on which teachers live and work" (Clandinin, Downey, \& Huber, 2009). If beginning teachers' stories to live by are continuously negotiated on their personal and professional landscapes, it is important to be attentive to this complex and messy phenomenon. 


\section{Thoughts for the Future}

Certainty is not a part of narrative inquiry, and we offer no knowledge claims to resolve the problems of beginning teacher attrition. We, however, show that by sanding beginning teachers' stories to fit into the boxes, we make invisible many of the lived experiences that make these individuals who they are and who they are becoming. Without knowing what has brought teachers to teaching, or what their imagined stories of teaching are, we wonder if we will ever know how we might keep them in the profession. Although beginning teachers are socialized as teachers long before they enter their formal education career, their stories to live by are being negotiated throughout their teacher education programs and into their teaching careers. It is important that beginning teachers are awakened to the possibilities of this complex process.

For beginning teachers to become reflective, spaces must be provided, in both teacher education and induction programs, for them to turn back upon the stories that brought them to becoming teachers. In becoming reflective to what has brought them to teaching, as well as to what they believe is important to them, and why it is important, beginning teachers may come to understand their imagined stories in a different way. The negotiation of their professional landscape and personal landscapes may become more purposeful if they understand how they have come to the bridge they need to cross; in bridging the gap to these imagined stories beginning teachers may be able to create forward-looking stories that include them in the profession.

\section{Notes}

1. Schaefer, L. (Under Review). Beginning Teacher Attrition: A Question of Identity Making and Identity Shifting. Teachers and Teaching: Theory and Practice.

2. There are multiple ways to conceptualize identity (Gee, 2000).

3. For further information see: Schaefer, L. (Under Review). Beginning Teacher Attrition: A Question of Identity Making and Identity Shifting. Teachers and Teaching: Theory and Practice. 
4. The narrative accounts, composed as the first level of analysis within the threedimensional narrative inquiry space, are included in Schaefer (2010). Here we focus on the stories that brought Kate and Shane to teaching, their shifting stories to live by, and their sustaining stories. We selected story fragments to show these shifts.

5. Kate's and Shane's quotes are italicized throughout.

\section{References}

Alliance for Excellent Education. (2005). Teacher attrition: A costly loss to the nation and to the states. (Issue Brief). Washington, DC: Author.

Clandinin, D. J. (1985). Personal practical knowledge: A study of teachers' classroom images. Curriculum Inquiry, 15(4), 361-385.

Clandinin, D, J., \& Connelly, F. M. (1995). Narrative inquiry: A methodology for studying lived experience. Research Studies in Music Education, 27(1), 44-54.

Clandinin, D. J., \& Connelly, F. M. (2000). Narrative inquiry: Experience and story in qualitative research. San Francisco: Jossey-Bass.

Clandinin, D.J., Downey, D.A., \& Huber, J. (2009). Attending to changing landscapes: Shaping the interwoven identities of teachers and teacher educators. AsiaPacific Journal of Teacher Education, 37(2), 141-154.

Clandinin, D. J., Huber, J., Humber, M., Murphy, S., Orr, A. M., Pearce, M., et al. (2006). Composing diverse identities: Narrative inquiries into the interwoven lives of children and teachers. New York: Routledge.

Connelly, F. M., \& Clandinin, D. J. (1999). Shaping a professional identity: Stories of educational experience. New York: Teachers College Press.

Estola, E. (2003). Hope as work: Student teachers constructing their narrative identities. Scandinavian Journal of Educational Research, 47(2), 181-203.
Flores, M. A. (2006). Being a novice teacher in two different settings: Struggles, continuities, and discontinuities. Teachers College Record, 10, 2021-2052.

Flores, M. A., \& Day, C. (2006). Contexts which shape and reshape new teachers' identities: A multi-perspective study. Teaching and Teacher Education, 22(2), 219-232.

Freedman, S. W., \& Appleman, D. (2009). "In it for the long haul": How teacher education can contribute to teacher retention in high-poverty, urban schools. Journal of Teacher Education, 60, 323-337.

Gee, J. P. (2000). Identity as an analytic lens for research in education. American Educational Research Association, 25, 91-125.

Greene, M. (1995). Releasing the imagination: Essays on education, the arts and social change. San-Francisco: Jossey-Bass.

Guarino, M. G., Santibañez, L., \& Daley, A. G. (2006). Teacher recruitment and retention: A review of the recent empirical literature. Review of Educational Research, 76(2), 173-208.

Hahs-Vaughn, D. L., \& Scherff, L. (2008). Beginning English teacher attrition, mobility, retention. The Journal of Experimental Education, 77(1), 21-53.

Ingersoll, R. M. (1999). The problem of under qualified teachers in American secondary schools. Educational Researcher, 28, 26-37. 
Lawson, H. A. (1983a). Toward a model of teacher socialization in physical education: The subjective warrant, recruitment, and teacher education. Journal of Teaching in Physical Education, 2(3), 3-16.

Lawson, H. A. (1983b). Toward a model of teacher socialization in physical education: Entry into schools, teachers' role orientations, and longevity in teaching (part 2). Journal of Teaching in Physical Education, 3(1), 3-15.

Lortie, D.C. (1975). Schoolteacher. Chicago: University of Chicago Press.

Macdonald, D. (1995). The role of proletarianization in physical education teacher attrition. Research Quarterly for Exercise and Sport, 66(2), 129-141.
Peske, G. H., Liu, E., Johnson, S. M., Kauffman, D., \& Kardos, S. M. (2001). The next generation of teachers: Changing conceptions of a career in teaching. Phi Delta Kappan, 83(4), 305-307.

Schaefer, L. (2010). A Narrative Inquiry into the Experiences of Two Beginning P.E. Teachers' Shifting Stories to Live By. Unpublished masters thesis, University of Alberta.

Smith T. M., \& Ingersoll, R. M. (2004). What are the effects of induction and mentoring on beginning teacher turnover? American Educational Research Journal, 41(3), 681-714.

Young, M. (n.d.). BrainyQuote.com. Retrieved June 22, 2010, from http://www.brainy quote.com/quotes/quotes $/ \mathrm{m} / \mathrm{margue}$ rite196731.htm.

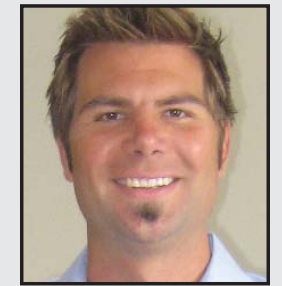

Lee Schaefer is a graduate student at the University of Alberta studying in the area of Secondary Education. His own experiences as a junior high school physical education teacher, mentor, and university facilitator inform his current master's thesis work which inquires into the experiences of beginning teachers. Working alongside Dr. Jean Clandinin and other narrative inquirers has furthered contributed to his understanding of the complexities and possibilities of narrative work.

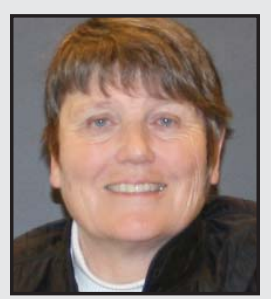

D. Jean Clandinin is Professor and Director, Centre for Research for Teacher Education and Development, University of Alberta. A former teacher, counselor, and psychologist, she co-authored with F. Michael Connelly four books and many chapters and articles. Their most recent book is Narrative Inquiry: Experience and Story in Qualitative Research. Jean also co-authored a 2006 book entitled, Composing Diverse Identities. Jean edited the Handbook of Narrative Inquiry: Mapping a Methodology (Sage, 2007). 